Asian American neighbourhoods that were decimated in the mid-twentieth century with the coming of the freeways. Due to the particular histories of Asian American communities, many of their neighbourhoods, particularly along the west coast, were immediately adjacent to downtown areas and thus very susceptible to gentrification from urban renewal during this period. Avila could have examined the Chinatowns and other Asian neighbourhoods of Seattle, Stockton, and Los Angeles to demonstrate Asian Americans' strategies of creative resistance and historic preservation.

Despite these minor critiques, however, Avila's The Folkore of the Freeway offers a window to the nuanced forms of resistance to freeway construction from many activist communities. Threading visual and textual analysis to stories of the freeway, Avila gives pause to the notion that black and brown communities were merely passive victims to the interstate highway system that bulldozed their neighborhoods decades prior. Most of all, his work gives scholars and policymakers alike a more comprehensive view of urban planning policies and can perhaps influence the current moment of "smart" growth policy and highly contested urban gentrification.

\title{
NOTES
}

${ }^{1}$ See for example, Jerry Gonzalez, “A Place in the Sun': Mexican Americans, Race, and the Suburbanization of Los Angeles, 1940-1980” (Ph.D. diss, University of Southern California, 2009) and Josh Sides, L.A. City Limits: African American Los Angeles from the Great Depression to the Present (Berkeley: University of California Press, 2004).

2 Joseph Bernardo, "From 'Little Brown Brothers' to 'Forgotten Asian Americans': Race, Space, and Empire in Filipino Los Angeles (Ph.D. diss, University of Washington, 2014).

Joseph Bernardo

Independant Scholar

\section{Jeffrey Rubin and Emma Sokoloff-Rubin, Sustaining Activism. A Brazilian Women's Movement and a Father-Daughter Collaboration (Durham: Duke University Press, 2013). 200 pp. \$22.95 Paperback.}

Jeffrey Rubin and Emma Sokoloff-Rubin's Sustaining Activism takes a very close look at the intimate, multifarious struggles of individuals deeply committed to building social movements from the ground up and (what is more difficult) sustaining them over time. Thematically and geographically, the book focuses on a women's movement spearheaded by female rural workers in the South of Brazil, 
and their efforts at obtaining and solidifying women's rights since the beginning of the re-democratisation of Brazil in 1985.

Methodologically, the book is a first-rate ethnographic account of the lives and personal objectives of the leaders of a social movement. It follows an essentially inductive path, as the narrative departs from very particular observations to suggest to the reader, reflections upon bigger issues. From this perspective, Rubin and Sokoloff-Rubin excel at showing how the lives of women such as Gessi Bonês, Vera Fracasso, Ivone Bonês, Mônica Marchesini, and many others, enable one to understand the obstacles to the creation of a women's movement in a rural setting, as well as the stumbling blocks to its continuity over time. Also noteworthy is the authors' long-term commitment to the project. Years upon years of intense, meticulously conducted participatory observation, coupled with the authors' outstanding capacity of chronicling events in an enthralling way, make the reader look forward to the next chapter of the movement's leaders' lives.

From another perspective, along with the book's primary source of strength comes a drawback. If one side of the coin is the richness of detail with which the lives of the women's movement in the city of Ibiraiaras has been described, the other side is a visible under-theorisation, and a rather timid analysis of the implications of the narrative for social movement theory and analysis. For instance, how does the power struggle amongst movement leaders - such as the one between Vera and her acquaintances - affect its direction and dynamic? What are the main sources of contention in the relationship between social movements and state institutions? Gessi faced a lot of opposition and criticism for taking up a governmental position. What did Gessi's colleagues who blatantly disapproved of her choice want the movement to accomplish, and how? Did these very same colleagues rethink their position after the friendly mayor lost the election and Gessi's progressive secretariat was dismantled? In other words, what are the gains and disadvantages of movements deeply involved in demand-making but which are reluctant to participate in public policy-making? How do the long-term financial considerations of individuals leading social movements revealed, for example, in Gessi's struggle to pay her bills after so many years of volunteer work - affect the very survival of these movements? What do the achievements of one group of women - such as the one under examination, which was led by white women, some of whom, as was the case of Mônica, own land - imply for other women's groups and the broader women's movement in Brazil? Finally, why are socially-progressive individuals, who seemed to have dedicated a big portion of their lives to attain gender equity, so timid to accept (or even talk about) the rights of sexual minorities? Why did not the authors ask other interviewees (one by one, in a private moment) about their thoughts and feelings regarding the relationship between Ivone and Vania? In this sense, what are the drivers of the "silence and speech" that the authors detected? These are 